
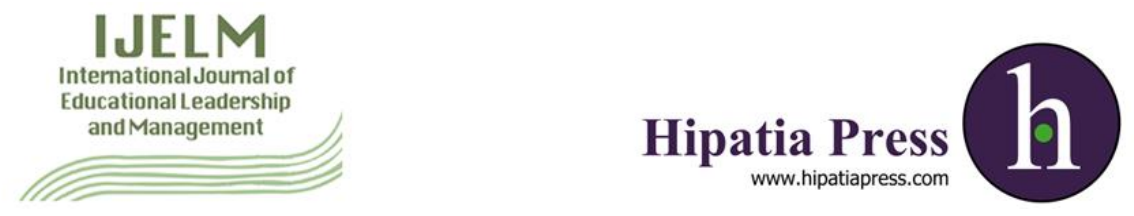

Instructions for authors, subscriptions and further details:

http://ijelm.hipatiapress.com

\title{
Extrovert Followership and its Impact on Agreeable Leadership
}

Syed Ali Abbas ${ }^{1}$

1) Poznan University of Economics. Poland

Date of publication: July $16^{\text {th }}, 2018$

Edition period: January 2018-July 2018

To cite this article: Abbas, S.A (2018). Extrovert Followership and its Impact on Agreeable Leadership. International Journal of Educational Leadership and Management, 6(2), 154-179. doi: 10.17583/ijelm.2018.3111

To link this article: http://dx.doi.org/10.17583/ijelm.2018.3111

\section{PLEASE SCROLL DOWN FOR ARTICLE}

The terms and conditions of use are related to the Open Journal System and to Creative Commons Attribution License (CCAL). 


\section{Extrovert Followership and its Impact on Agreeable Leadership}

Syed Ali Abbas

Poznan University of Economics

\section{Abstract}

This study recons the need for research on effective role of followership in mentoring a leader to set pattern or direction for leader. A reinvented concept of leader being a team man needs active participation from followers in changing business dynamics. The sample consisting of middle level management having leader (heads/ supervisors from education sector) above it has been taken and results are achieved using inferential statistics, so to verify the need of followers for result oriented leadership. The results depict that certain personality traits backed by "Big Five Model" are found to be important for followers to have an impact on leader's decision making. As this study analyses the mutual characteristic of leader follower relation statistically while putting follower on the fore front, the originality of study is ensured. As for limitation, this study may show different results as per variant geographical and economical regions in which followers' expectations may vary accordingly. 


\section{El Seguidor Extrovertido y su Impacto en un Liderazgo Agradable}

Syed Ali Abbas

Poznan University of Economics

\section{Resumen}

Este estudio reconsidera la necesidad de investigar sobre el papel efectivo de los seguidores en la tutoría de un líder para establecer el patrón o la dirección del líder. Un concepto reinventado de líder siendo un hombre de equipo que necesita la participación activa de los seguidores en la dinámica empresarial cambiante. La muestra consiste en la gestión de nivel medio que tiene el líder (jefes / supervisores del sector educativo) los resultados se obtienen utilizando estadísticas inferenciales, para verificar la necesidad de seguidores para el liderazgo orientado a resultados. Los resultados muestran que ciertos rasgos de personalidad respaldados por el "Big Five Model" son importantes para que los seguidores tengan un impacto en la toma de decisiones del líder. Este estudio analiza la característica mutua de la relación del seguidor líder estadísticamente, mientras que pone al seguidor en un primer plano, la originalidad del estudio está garantizada. En cuanto a la limitación, este estudio puede mostrar resultados diferentes según las diferentes regiones geográficas y económicas en las que las expectativas de los seguidores pueden variar en consecuencia.

Palabras clave: liderazgo, cambio organizacional, entrenamiento, relaciones humanas, seguidores 


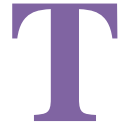

He word "Leadership" has got such immense appeal in it that whenever this word is associated with some person or individual, leaders in past, their personality traits etc. and in present Jooste \& Frantz (2017) have recently put forward suggestions in developing leadership skills as well. In general, researchers associate traits and features liker risk taker, initiator, daring, innovative, problem solving etc. for leaders but often neglect the most important aspect for becoming a perfect leader, and that is "A Perfect Follower". However, across meaningful intervals in past, researchers showed a shift from focusing on leadership traits to Followership identity, to analyse the aspects and key determinants which make someone a follower. Baker (2007) has significantly contributed to the discussions in developing constructs regarding followership which were lacking in the past, and this is exactly the objective of this research I.e. to look upon the characteristics, beliefs, values, attitude and a very self of the true follower; his/her impact and his/her role as a decisive factor to choose and to correct his/her leader.

Almost 30 years ago, article by Kelley, "In praise of Followers" (1988) focuses on the active role of followers in organizational success as success is not entirely dependent on dynamic leaders. The concept that followers are more than just subordinates was initiated by Chaleff's (1995) about courageous followers. From there on the entire future discussion started on "Followership" because of primary works by Kelley's (1988) and Chaleff's (1995) publications; clearly focusing upon followership as being an integral or utmost part of an effective leadership and their theories proposed styles, attitude, behaviours and characteristics of followers and the interlinkage of leader follower relation

\section{Focus on Leaders rather than Followers}

In early times, the common view about leadership was that leaders actively led the followers, who are bound to follow the latter obediently, then Follett (1996) observed that why were followers ignored as the spot light shone brightly on leaders. Early leaders are called Greatmen, specifically in the era of Preindustrial and Pre-bureaucratic period, and the 
158 Abbas, S.A - Extrovert Followership and its Impact on Agreeable Leadership

leadership qualities and skills that takes Greatmen away from rest of the ordinary class of people were considered as inborn and inherited abilities which can't be acquired (Galton, 1900). The individuals who were not blessed with these abilities were considered as the unlucky fellows who couldn't acquire them and thus had no other option to become an obedient and well directed follower.

\section{Idealized Leader overshadows Followers}

Hollander (1974) argued that the primary role of an organizational leader was transformed into executive or a managerial role, thus directing the activities and identifying the role of subordinates. He further observed that leaders were thought to hold the authority which had given followers the ready-made behaviour of accepting him/her as a leader and him being different. With this difference, a leader's fixed position was respected, regarded and honoured and the role of a follower automatically got less attention. Vanderslice (1988) came up with the idea of clever leadership skills I.e. Operationalizing Leadership which surpasses the followers to believe that all power is deserved by the leader. Further Meindil, Ehrlich and Dukerich (1985) condemned the overall idealized attitude of the leader in the eyes of public where the cultural view of a heroic and romanticized hero lead people to attribute all glory and failure. According to them, it was more like a culture which made leaders what they thought of themselves and in general it took follower on further down side, so the concept of idealized leader overshadowed the follower in all walks of life. Even this practice in family structure created variances within the relations where an individual being elder was a born and accepted leader.

\section{Social Change Affects Followers}

The Social impact on leader follower relation is been the key element for recognizing follower as an important player in decision process, and the initial flames that formulated the basis of a responsive and proactive follower appeared exactly after World War II. This occurred because corporate organizational structures flattened and thus power, responsibilities 
and authorities divided to number of hands including the conventionally dependant and spoon feeder followers. Due to this, leaders started expecting and believing their followers to be risk takers and initiators (Lippitt, 1982). Followers in turn were good enough to observe it as a challenge but avoided the risk of accepting new responsibilities due to lack of training (Lippit 1982) as a result of which the philosophy of relying on followers took halt as the business organization got failed to make their mark and leaders therefore started considering their followers as ill equipped to manage the business complexities and their inability to collaborate with their superiors (Berg, 1988). In response, the weight shifted towards leaders again and researchers' focus of study was totally dedicated on developing new leadership skills. Although, there were also seen some suggestions to develop those skills in followers as well, but neither any serious efforts were made on the leader followership relationship or on the demands placed on each role (Berg, 1998). The organizational pressure in 1980s and early 1990s which resulted in heavy downsizing was considered as an opportunity to few followers who thought about it as an opportunity to get in touch with their higher management and to organize a new psychological contract by taking a partnership role with their leaders (Potter \& Rosenbach, 2006). This takes us again to the purpose of study which is to identify if there exists an important role of followers on leader's decision making? How much do they influence leaders in all the ways and will tomorrow's leader be led by followers? And to be a good leader does one need good followers?

\section{Moving to a View of Active Followers}

Regardless of the fact the management scholars didn't notice any strong linkages between the leader follower efficient and interdependent relationship, but psychologists and social scientists had observed the factual reality between the two and Segmund (1921) and Formm in 1941, identified a psychological link between leader and followers. Erikson discussed a link between leader and followers in 1975. In anthropology, Mead (1961) discussed the importance of examining the psychological relationships between leader, lieutenant, and follower. This broadened the circle of his research to the lives of the individuals, their cultural and those psychological and demographics factors that affect the individuals and their roles. 
160 Abbas, S.A - Extrovert Followership and its Impact on Agreeable Leadership

Sanford (1950), a social scientist observed that "leadership is an intricate relation between leader and followers' and that leaders had to maintain an effective, easy and understanding based relationships with their subordinates or followers, otherwise things may get dodgy and the desired results for achieving organizational loyalty, commitment and ultimately success would just become not more than a dream. Homans (1950) discussed the "human group" of the elites; the ruling class must consider the undying and evolving necessity of followership importance, non-acceptance of which may affect the organizational success. In 1961, Homans was among the early writers to describe a process of exchange between leader and group members in which both parties give and take resources I.e., a collaboration and joint relation where an employee must be quickly compensated for its efforts and performance for its organization to retain the employer's loyalty and dedication towards his/her bosses (Bargal \& Schmid, 1989). These researches proved out to be a magnificent work for followers and it was a time to recognize the subordinates or follower at a higher stage where their say, their rights and their opinion got noticed (Hollander et al., 1990).

Hollander (1974) raised questions and identified topics that became basic themes and issues in active followership. These included the ideas that leaders and followers are two integral roles and processes that should not be confused by the people who are filling them. Hollander made it clearer by emphasizing upon the fact that at some point of time and to some extent leaders were also followers and they also have come through the same process, with the same hierarchy or nearly with the same organizational structure as their present followers are experiencing now. The followers could be highly innovative and moderate in approach and can facilitate the upper level management to the best possible they can.

It was now a time for management researchers to write about followership and made the leaders believe that there exists a strong bondage between them and their followers. The authors urged leaders to focus on followers for the total improvement in managers' leadership skills, most specifically about followers as what they want, how they want to be operated 
and how can they prove out to be an unmatchable asset. Wortman (1982) called these works "leadership studies that incorporate data about followers".

A few researchers followed Hollander's approach by examining the leader-follower relational component of active followership. As an evidence of which, Herold (1977) used a laboratory study to demonstrate that how each party could influence the other party's behaviour in a leader-follower relationship. He contributed in terms of literature review which sets basis for latest researchers on the followership importance and the idea that leader's effectiveness must be beyond analysing the effects of leader behaviour on subordinates as subordinate's effects on leader's behaviour must also be considered. A leader needs to be calmer, more smooth and easy with the follower and should give follower enough room to work in his desired lines for consistent efficacy.

Frew (1977) contributed to followership theory by focusing on the importance of followers to a leader's success. His contributions were only beginning steps because he examined followers to determine what kinds of leadership styles they preferred in their supervisors. His conclusions focused on making leaders more effective and improving organizational effectiveness by reducing managerial error. Followers were not the focus of his conclusions. Additionally, he studied followers and followership but did not define the terms.

\section{The Power Concept}

Steger, Manners \& Zimmerer, (1982) raised two important issues that reshaped the traditional approach of dictator's organizational leader methodology. The two important aspects he focused were organizational structure and the use of power. In his view, he wanted to have a solid evidence of the fact that how much freedom the organization gave a manager to reward or punish subordinates. He forced the managers to limit their power to the extent that they shouldn't exercise it excessively so that it hurts the followers. He rather convinced the leaders to use it more like a managerial power that should be in line with a follower's style. A supportive and developmental power, a devious and manipulative power to motivate followers to support organizational change 
162 Abbas, S.A - Extrovert Followership and its Impact on Agreeable Leadership

\section{Individual Internalization as follower or leader}

Individual internalization is a state where individuals come to incorporate the identity of leader or Follower as part of their self-concept (Derue, 2010). Human Self portrays a vital role in making him believe whether he should be a leader or follower. A traditional follower is the one where he himself is bound to obey some upper authority over him. He feels problem in decision making at his own and internally has made up his mind of being a follower in any case as the capacity or willingness to follow a leader (Ricketts, 2004) simply makes someone a follower. Whereas a modern follower is like a leader in approach, who yet being on follower stage, is a leader in himself. He wants the leader to work and operate in a way, he wants his leader to be and it looks possible when there exist followers like him within the same organization.

Developing insights into the leadership identity construction process is important because Individuals' identities as leaders and followers are thought to be significant drivers of their subsequent thought, affect, motivation and action (Gardner et al., 1998). Indeed, prior research suggests that seeing oneself as a leader not only enhances one's motivation to lead (Chan, Kim, Drasgow \& Fritz, 2001; Kark \& Dijk, 2007) and engagement in the leadership process, but also promotes the seeking out of leadership responsibilities and opportunities to develop leadership skills.

\section{Identity Construction in Organizational \& Social context}

Identity involves the meaning attached to the self (Gecas, 1982). Any particular identity can be conceptualized along three levels of self-construal: individual, relational and the collective (Brewer \& Gardner, 1996). Individual internalization involves "the creation of new aspects of the self that relates to the leader (or follower) role (e.g., growth in the leader subidentity)" (Hall, 2004: 157).

In socio organizational context, a leader follower relationship has to be in line with itself and there must be enough clarities of roles for proper 
functioning of organization. When this clarity about the roles of follower and leaders exist, there is greater acceptance of the person constructed as leader, to exert influence over the person constructed as follower. When this clarity is missing, then one can expect increased conflict and tension in the relationship (Collinson, 2005). In this sense, the construction of a leadership identity and the respective identities as leader and follower are inputs into the quality of leader-follower relationships (Graen \& Uhl-Bien., 1995); clearly focusing that role of both the parties must not be mixed for proper functioning and both understand their respective roles. If this role identify is cleared then leadership will be influential for a follower, and if in any case this is missing then there will be uncertainty, conflicts and miss alignment in the organization.

\section{Claiming \& Granting the Identity}

Another important and not to be missed factor in developing followership identity is claiming and granting someone with his/her identity. Following are the two most important parameters of claiming and granting of identities

\section{Direct Verbal Acts}

Claiming and granting activities by both the leaders and followers is an important aspect of the respective self-concept. In this regard Claiming refers to the actions people take to assert their identity as either a leader or follower. For example, we look towards Lebron James's statement to the press upon joining his NBA basketball team and the 19-year old said, "I'm a leader. I am the leader of this team". Or, consider people in organizations who say, "I'm just not the leader-type."

Both statements are verbal assertions that represent claims to a leader or follower identity in a specific context. As far as Granting is concerned these are the actions that a person takes to bestow a leader or follower identity onto another person. Grants can come from individuals actively involved in work or from people who simply notice and endorse a person as a leader (e.g., a colleague from another department). This all is called claiming and granting through direct verbal acts. 
164 Abbas, S.A - Extrovert Followership and its Impact on Agreeable Leadership

\section{Nonverbal Acts}

A leader or follower does not necessarily have to show themselves as a leader or follower through their words, as their postures, gestures, actions and body movement can do the maximum for them. An indirect gesture of a person to claim himself a leader non-verbally could be his confident posture I.e. the way he sits in a meeting or by sitting at the exact centre of the meeting table whereas a follower in the same scenario could be the person who hates to give his opinion and only speaks when he is asked to speak or contribute in the debate whenever he is forced to.

To sustain and continue leader follower relationship, there must include three important aspects I.e. credibility, clarity and visibility of grants and claims. The saliency and visibility of the information is high (Fiske, Kenny \& Taylor, 1982), and the information is credible (Chaiken \& Maheswaran., 1994; Fisher, Ilgen \& Hoyer, 1979). On extending this approach to leader follower relation, the respective claims and grants of being leader and follower would only be considered meaningful if visible, clear and credible. Consider an individual who is elected to be the designated leader of a group of 20 in a public election process during a meeting. This grant of a leader identity is clear, visible, and credible. (DeRue et al, 2010). Clear claims and grants create transparency that how individuals see themselves and how those individuals are viewed within the social context.

\section{Motivation, Rewards and Risk Relation}

Motivation and rewards have always been an inspiring factor for an individual at any level. A well-established tenet in our understanding of human motivation is that self-interest shapes human behaviour and action (Miller, 1999; Miller \& Ratner, 1998; Schwartz, 1986) but in leader follower relation it will only be exercisable if instrumental, motivational and financial rewards are associated with this. In this case, both the leader or follower would love to be claimed or granted as leaders and followers, and the reciprocal result is obvious if there is high risk involved in their job. So. the amount of instrumental risk involved in leadership depends in part on the 
likely fate of the group or organization, as groups' successes and failures are frequently attributed to the leader (Meindl, et al, 1985), whereas followers will also less likely to be on main frame and would happier in just being a follower.

This leads us to hypothesis development backed by big five model, which is numerously used in accessing the personality traits of respondents regarding their employments, health and performance (Khan, Ahmed \& Abid, 2016). Although, the model explains five different personality dimensions that an individual possesses I.e. Openness, Consciousness, Extroversion, Agreeableness and Neuroticism, the focus in this study will be on one personality trait of followers I.e. Extroversion and the Agreeableness of leaders will be taken as the other construct, as per opinion of followers about their supervisors/ leaders.

Table 1:

Big Five Constructs and Attributes

\begin{tabular}{|c|c|c|}
\hline OPENESS & 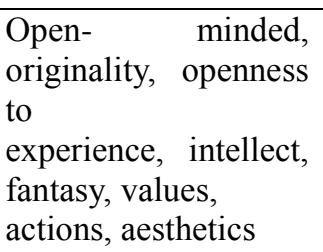 & $\begin{array}{l}\text { (John \& Srivastave, 1999; } \\
\text { Costa \& McCrae 2008) }\end{array}$ \\
\hline CONCIOUSNESS & $\begin{array}{l}\text { Conscientious, } \\
\text { control, constraint; } \\
\text { competence, self- } \\
\text { confidence and } \\
\text { achievement striving }\end{array}$ & $\begin{array}{l}\text { (John \& Srivastave, 1999; } \\
\text { Nia \& Besharat, 2010) }\end{array}$ \\
\hline EXTROVERT & $\begin{array}{l}\text { Extrovert, } \\
\text { enthusiasm, energy, } \\
\text { warmth, } \\
\text { gregarious, } \\
\text { assertiveness, } \\
\text { excitement } \\
\text { seeking }\end{array}$ & $\begin{array}{l}\text { (John \& Srivastave, 1999; } \\
\text { Costa \& McCrae 2008) }\end{array}$ \\
\hline
\end{tabular}


166 Abbas, S.A - Extrovert Followership and its Impact on Agreeable Leadership

\begin{tabular}{|c|c|c|}
\hline AGREEABLENESS & $\begin{array}{l}\text { Altruistic, } \\
\text { affectionate, } \\
\text { agreeable; } \\
\text { straight forward; } \\
\text { tender-minded; trust } \\
\text { and compliance }\end{array}$ & $\begin{array}{l}\text { (John \& Srivastave, 1999; } \\
\text { Nia \& Besharat, 2010) }\end{array}$ \\
\hline NEUROTICISM & $\begin{array}{l}\text { Neurotic; } \\
\text { Nervousness, } \\
\text { negative } \\
\text { affectivity, } \\
\text { neuroticism, anxiety, } \\
\text { hostility, depression }\end{array}$ & $\begin{array}{l}\text { (John \& Srivastave, 1999: } \\
\text { Costa \& McCrae 2008) }\end{array}$ \\
\hline
\end{tabular}

H1: Extrovert follower has a significant impact on leadership (Leaders' Agreeableness)

Ho: Extrovert follower doesn't have significant impact on leadership (Leader' Agreeableness)

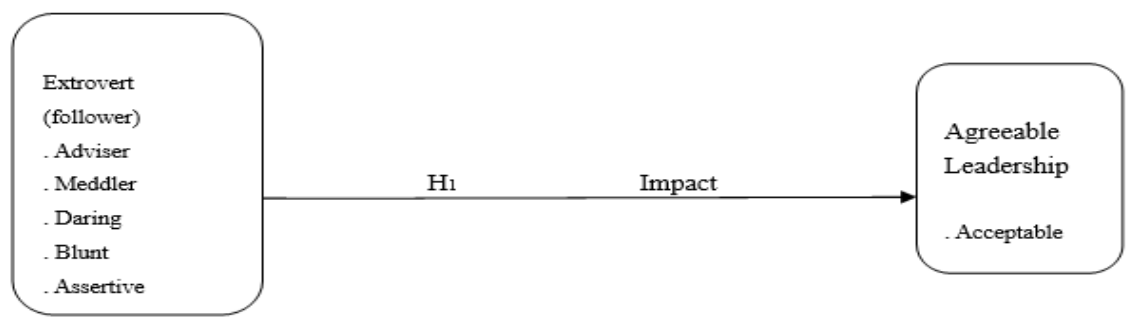

Figure 1. Hypothesis

As being extrovert is considered part of the traits showed in fig 1. and table 1 , the hypothesis will aim to identify which personality feature of being extrovert affects or has an impact on leader's agreeableness. 


\section{Methodology}

To test the hypotheses empirically, questionnaires on "agreeableness scale" were sent electronically to middle line managers of multinationals and respondents mainly from educational sector. Convenience sampling technique was used using online forms and the response rate was 53\%. The purpose for selecting middle line management was to perceive its evaluation as followers who are directly under the influence of boss and decisionmaking supervisors. Getting responses from them with set of questions showing their influence as followers on their bosses/ supervisors may signify if their say really set direction for leaders or leaders take their suggestions to maintain their leadership status, which is the theme of this research. Follower being "Extrovert" is taken from Big Five model as an independent variable justified by the attributes from questions 4 to 7 whereas the agreeableness of leaders as per followers' response from question 8 to 10 is taken as dependent variable. The responses are to be evaluated using descriptive and regression analysis for hypothesis testing.

\section{Findings and Discussions}

The mean value for the first three questions showing followers' quality as an attentive, loyal and adviser to some good extent as the values normally fall between strongly agree and agree. Also, the standard deviation is not greatly deviated thus showing modern followers are understanding and performing their duty as an obedient follower (table 2). 
168 Abbas, S.A - Extrovert Followership and its Impact on Agreeable Leadership

Table 2

Descriptive Statistics (a)

\begin{tabular}{|l|r|r|r|r|r|}
\cline { 2 - 6 } \multicolumn{1}{l|}{} & Attribute & Min. & Max. & Mean & Std. Deviation \\
\hline $\begin{array}{l}\text { I listen to my leader } \\
\text { carefully }\end{array}$ & Attentive & 1 & 3 & 1.46 & .600 \\
\hline $\begin{array}{l}\text { I want my leader to } \\
\text { succeed and come out of } \\
\text { tough situations }\end{array}$ & Loyal & 1 & 3 & 1.54 & .682 \\
\hline $\begin{array}{l}\text { I give suggestions to my } \\
\text { leader if he/she asks for }\end{array}$ & Adviser & 1 & 4 & 1.74 & .818 \\
\hline
\end{tabular}

Evident from the table 2, the mean value for the first three questions showing followers' quality as an attentive, loyal and adviser to some good extent as the values normally fall between strongly agree and agree. Also, the standard deviation is not greatly deviated thus showing modern followers are understanding and performing their duty as an obedient follower.

Table 3

Descriptive Statisics (b)

\begin{tabular}{|l|r|r|r|r|r|}
\hline Construct & Attributes & Min. & Max. & Mean & Std. Deviation \\
\hline $\begin{array}{l}\text { EXTROVERT } \\
\begin{array}{l}\text { I give suggestions to my } \\
\text { leader even if he/she } \\
\text { doesn't ask }\end{array}\end{array}$ & Meddler & 1 & 5 & 2.77 & 1.180 \\
\hline $\begin{array}{l}\text { I don't fear speaking in } \\
\text { the public/ meeting in } \\
\text { front of him/her }\end{array}$ & Daring & 1 & 4 & 2.03 & \\
\hline
\end{tabular}




\begin{tabular}{|l|r|r|r|r|r|}
\hline $\begin{array}{l}\text { I don't mind showing } \\
\text { disagreement to my } \\
\text { leader's point of view, if } \\
\text { I find him/her wrong }\end{array}$ & Blunt & 1 & 5 & 2.92 & .957 \\
\hline $\begin{array}{l}\text { I try to impose my logic } \\
\text { on my leader }\end{array}$ & Assertive & 1 & 5 & 3.64 & 1.038 \\
AGREEABLE & Trust & 1 & 4 & 2.72 & \\
\hline $\begin{array}{l}\text { Most of the times I find } \\
\text { leader implementing my } \\
\text { ideas/ proposals }\end{array}$ & & & & \\
\hline $\begin{array}{l}\text { Mostly leader accepts } \\
\text { my point after strong } \\
\text { arguments/debates }\end{array}$ & Acceptable & 1 & 4 & 2.49 & .686 \\
\hline $\begin{array}{l}\text { My leader credits me for } \\
\text { my contribution in } \\
\text { overall success of the } \\
\text { organization }\end{array}$ & Admirable & 1 & 4 & 2.08 & \\
\hline
\end{tabular}

The results in above (table 3) are more like decider and showing variations in responses. That also proves that not every follower is blunt, despite there are quite a few who are forceful in their opinions and daring who try to impose their logic on leader and want to direct their approach if they find something wrong in the larger interest of organization. Most of these values falling in somewhat agree column exactly show the routine behaviour of common employees who play safe and give their opinion in safe zones, yet very low values falling in the zone of disagree and strongly disagree is an alarming sign for the leaders that gone are the times when followers will just follow without any discussion and closed eyes. They will at least be expecting, commenting and silent if they don't agree with 
170 Abbas, S.A - Extrovert Followership and its Impact on Agreeable Leadership

something but they won't be exactly easy going with whatever the leader commands. They want their opinion to be heard and being implemented to some extent as well. They want to be a part of process and discussions. The mean value for being daring and blunt is a sign of concern for modern day leaders; these are the people who have strong voice in the organization for which they don't mind being disagreeing with the leader. In fact, having this kind of people are must in organization for its productivity as yes-men might turn out to be less productive and conventional. In the last row high, mean value of followers for being leader in future is another productive sign showing modern day follower to see in him/ her with all the traits and qualities of being a leader which further depict their intention and expectations from the leader and organization.

\section{Hypothesis Testing}

Table 4.

\section{Correlations}

\begin{tabular}{|ll|l|l|l|l|l|}
\hline & & Acceptable & Meddler & Daring & Blunt & Assertive \\
\hline Pearson & Acceptable & 1.000 & & & & \\
Correlation & Meddler & -.017 & 1.000 & & & \\
& Daring & .366 & .217 & 1.000 & & \\
& Blunt & .049 & .217 & .225 & 1.000 & \\
Assertive & .148 & .339 & .251 & .316 & 1.000 \\
\hline Sig. (1-tailed) Acceptable & & & & & \\
Meddler & .460 &. & & & \\
Daring & .011 & .092 &. & & \\
Blunt & .384 & .092 & .084 &. & \\
Assertive & .184 & .017 & .062 & .025 &. \\
\hline
\end{tabular}


Table 5.

Excluded Variables ${ }^{a}$

\begin{tabular}{|c|c|c|c|c|c|c|}
\hline \multirow{2}{*}{\multicolumn{2}{|c|}{ Model }} & \multirow[b]{2}{*}{ Beta } & \multirow[b]{2}{*}{$\mathrm{T}$} & \multirow[b]{2}{*}{ Sig. } & \multirow{2}{*}{$\begin{array}{c}\text { Partial } \\
\text { Correlation }\end{array}$} & Collinearity Statistics \\
\hline & & & & & & Tolerance \\
\hline \multirow[t]{3}{*}{1} & Meddler & $-.101^{b}$ & -.639 & .527 & -.106 & .953 \\
\hline & Blunt & $-.035^{\mathrm{b}}$ & -.222 & .825 & -.037 & .949 \\
\hline & Assertive & $.060^{\mathrm{b}}$ & .377 & .708 & .063 & 937 \\
\hline
\end{tabular}

a. Dependent Variable: Acceptable b. Predictors in the Model: (Constant), Daring Due to significance value higher than 0.05 and some negative correlations, the new intended attributes for follower being Meddler, Blunt and Assertive are excluded and does not fit in model.

Table 6.

Model Summary $b$
\begin{tabular}{|l|c|r|r|r|r|}
\hline Model & $\mathrm{R}$ & R Square & \multicolumn{1}{|c|}{$\begin{array}{c}\text { Adjusted R } \\
\text { Square }\end{array}$} & $\begin{array}{l}\text { Std. Error of the } \\
\text { Estimate }\end{array}$ & $\begin{array}{c}\text { Durbin- } \\
\text { Watson }\end{array}$ \\
\hline 1 & $.366^{\mathrm{a}}$ & .134 & .111 & .776 & 1.944 \\
\hline
\end{tabular}

a. Predictors: (Constant), Daring b. Dependent Variable: Acceptable

Table 7.

\begin{tabular}{|l|r|r|r|r|r|}
\hline Model & Sum of Squares & df & Mean Square & F & \multicolumn{1}{|c|}{ Sig. } \\
\hline 1 Regression & 3.455 & 1 & 3.455 & 5.73 & $.022^{\mathrm{b}}$ \\
& 22.289 & 37 & .602 & & \\
Residual & 25.744 & 38 & & & \\
Total & & & & \\
\hline
\end{tabular}

a. Dependent Variable: Acceptable. b. Predictors: (Constant), Daring 
Analyzing the attribute daring by looking at its $\mathrm{R}$ squares $(0.11)$ and significance value $(0.02)$ which is less than 0.05 , the null is rejected and daring being one of the attributes of extrovert follower proves that extrovert follower has a significant impact on leader's agreeableness. So, the final graphical interpretation of hypothesis is depicted in fig 2 .

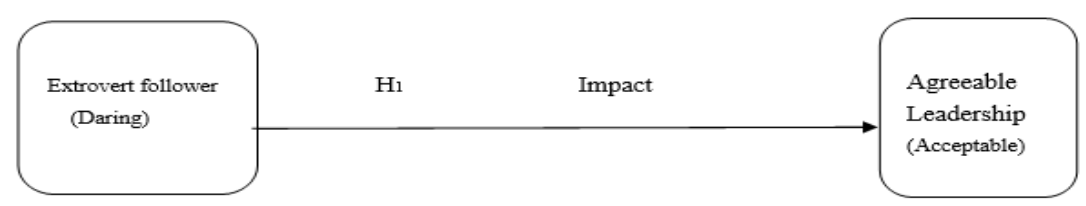

Figure 2. Proved Hypothesis

\section{Conclusions}

Followership undoubtedly or unquestionably should be the topic of concern for researchers these days, not only because there has already been written a lot about leadership, leadership styles, leadership control etc. but also because of the importance a modern-day follower (employee) possess. While Peker, Inandi \& Gillic (2018) discusses various relationship between democratic and autocratic leadership styles of school administrators and mobbing teachers experience, this study extends the discussion towards active role followers and their contribution to effective leadership. The followers are making it tough for leaders and they are on such edge of freedom that their experience, skills \& competencies justify their decisionmaking attitude, even in terms of choosing or selecting as who should or shouldn't be their leader. As Amiridis (2018) studies the practical and theoretical concerns when leaders are confronted with situations of moral crisis, agreeable leadership could be one of the ideas discussed in this study that may be used to cope with these scenarios. 
Other than that, there still exists a wide room for leaders to remain in the lime light, not by tracing their conventional, authoritative and hardhitting leadership style but by creating, enhancing and maintaining such a cordial or friendly environment that makes follower to feel comfortable enough to feel him/her a leader's follower. Taking into consideration, Amann's and Kruckeberg's (2017) point of view that entails for followers' loyalty on the basis of leaders' ability to solve complexities, this research makes its point clear by demanding active role of followers for task-oriented leadership, even if the followers are daring in approach. In short, if strengthening the throne demands active followership then leaders should let it happen, as at the end of the day they will still be recognized as leaders, otherwise the followers of 21 st century will become leaders.

\section{Implications for Future Research}

This research opens new horizon for turning from leadership to followership concept. It may allow researchers to pen books on importance, effectiveness, traits and personnel characteristics required for followership. Also considering modern dynamics this research can further be in cooperated in multiple fields to get an overview of active followership and their demanding role in changing political dynamics worldwide. Further studies on it may be used to gage future election campaigns as to analyze followers' expectations of their leaders and even designing strategies accordingly. In academics and corporate world, it shows immense need to design future courses on Followership to be taught in business and psychological studies. 
174 Abbas, S.A - Extrovert Followership and its Impact on Agreeable Leadership

\section{References}

Amiridis, K. (2018). The Shadow of Sophocles: Tragedy and the Ethics of Leadership. Business Ethics Quarterly, 28(1), 15-29. doi:10.1017/beq.2017.39

Amann, W., \& Kruckeberg, K. (2017). Advanced Leadership Insights: How to Lead People and Organizations to Ultimate Success. Charlotte, North Carolina: Information Age Publishing.

Baker, S. D. (2007). Followership: The Theoretical Foundation of a Contemporary Construct. Journal of Leadership \& Organizational Studies. 14(1), 55-60.

https://doi.org/10.1177\%2F0002831207304343.

Bargal. D., \& Schmid. H. (1989). Recent Themes in Theory and Research on Leadership and Their Implications for Management of the Human Services. Administration in Social Work, 13, 37-54.

https://doi.org/10.1300/J147v13n03_03

Berg, D.N. (1998). Resurrecting the muse: Followership in organizations. In E. B. Klein, F. Gabelnick, \& P. Herr (Eds.), The psychodynamics of leadership. 27-52.

Brewer, M. B., \& Gardner, W. (1996). Who is this" we"? Levels of collective identity and self representations. Journal of Personality and Social Psychology, 71, 83-93.

Chaiken, S., \& Maheswaran, D. 1994. Heuristic processing can bias systematic processing: Effects of source credibility, argument ambiguity, and task importance on attitude judgment. Journal of Personality and Social Psychology, 66, 460-460.

Chaleff, I. (1995). The courageous follower. San Francisco: Berrett-Koehler Publishers.

Chan, K.Y\& Drasgow, F. (2001). Toward a theory of individual differences and leadership: Understanding the motivation to lead. Journal of Applied Psychology, Vol 86(3), 481-498. 
Collinson, D. 2005. Dialectics of leadership. Human Relations, 58, 14191442.

DeRue, D. \& Ashford, S. J.(2010). Who will lead and who will follow: a social process of leadership identity construction in organizations. Academy of management review, Vol.35(4), 627-647.

Fisher, C. D., Ilgen, D. R., \& Hoyer, W. D. (1979). Source Credibility, Information Favorability, and Job Offer Acceptance. Academy of Management Journal, 22, 94-103.

Fiske, S. T., Kenny, D. A., \& Taylor, S. E. (1982). Structural Models for the Mediation of Salience Effects on Attribution. Journal of Experimental Social Psychology, 18, 105-127.

Follett, M.P. (1949). The essentials of leadership. London: Management Publications Trust, Ltd.

Frew, D. R. (1977). Leadership and followership. Personnel Journal, 56(2), 90-95.

Galton, F. (1869). Hereditary genius. New York: Appleton.

Gardner, W.L., Avolio, B.J., Luthans, F., May, D.R., \& Walumbwa, F. (2005). "Can you see the real me?" A self-based model of authentic leader and follower development. Leadership Quarterly, $16,343-372$.

Graen, G. B., \& Uhl-Bien, M. (1995). Relationship-based approach to leadership: Development of leader-member exchange (LMX) theory of leadership over 25 years: Applying a multilevel multidomain perspective. The Leadership Quarterly, 6, 219-247.

Gecas, V. (1982). The self-concept. Annual Review of Sociology, 8, 1-33. Hall, D. T. (2004). Self-awareness, identity, and leader development. In D. V. Day, S. J. Zaccaro, \& S. M. Halpin (Eds.), Leader development for transforming organizations: 153-176. Mahwah, NJ: Lawrence Erlbaum Associates.

Hanges, P., Offerman, L., \& Day, D. (2001). Leaders, followers and values: Progress and prospects for theory and research. Leadership Quarterly, 12, 129-131. 
176 Abbas, S.A - Extrovert Followership and its Impact on Agreeable Leadership

Herrold, D. M. (1977). Two-way influence processes in leader-follower dyads. Academy of Management Journal, 20 (2), 224-237.

Hollander, E.P. (1974). Processes of leadership emergence. Journal of Contemporary Business, 3, 19-33

Homans, G. C. (1950) The Human Group. New York: Harcourt, Brace and Company.

Howell, J.M., \& Shamir, B. (2005). The role of followers in the charismatic leadership process: Relationships and their consequences. Academy of Management Review, 30(1), 96-112.

Jooste, K., \& Frantz, J. (2017). Self-leadership traits of academics to conform to a changing higher-education environment. African Journal of Health Professions Education, 9(4), 199-202. doi:10.7196/AJHPE.2017.v9i4.823.

Kark, R., \& van Dijk, D. (2007). Motivation to lead, motivation to follow: The role of the selfregulatory focus in leadership processes. The Academy of Management Review, 32, 500-528.

Kelley, R.E. (1988). In praise of followers. Harvard Business Review, 66, 142-148.

Kelley, R. E. (1992). The power offollowership: How to create leaders people want to follow and followers who lead themselves. New York: Doubleday

Khan, B., Ahmed, A., \& Abid, G. (2016). Using the 'Big-Five'-For Assessing Personality Traits of the Champions: An Insinuation for the Sports Industry. Pakistan Journal Of Commerce \& Social Sciences, 10(1), 175-191.

Lippitt, R. (1982). The Changing Leader-Follower Relationships of the 1980s. The Journal of Applied Behavioral Science, 18(3), 395 403. doi.org/10.1177\%2F002188638201800312

Mead, M. (1949). Problems of leadership and mental health. World Federation for Mental Health Bulletin (1949- 1952), 1(6), 7-12. 
Meindl, J., Ehrlich, S., \& Dukerich, J. (1985). The Romance of Leadership. Administrative Science Quarterly, 30(1), 78-102. doi:10.2307/2392813.

Meindl, J., \& Ehrlich, S. (1987). The Romance of Leadership and the Evaluation of Organizational Performance. The Academy of Management Journal, 30(1), 91-109. Retrieved from http://www.jstor.org/stable/255897

Miller, R.L., Butler, J., \& Cosentino, C.J. (2004). Followership effectiveness: An extension of Fiedler's contingency model. Leadership and Organization Development Journal, 25(3/4), 362368.

Miller, D. T., \& Ratner, R. K. (1998). The disparity between the actual and assumed power of selfinterest. Journal of Personality and Social Psychology, 74: 53-62.

Peker, S., Inandi, Y., \& Giliç, F. (2018). The Relationship between Leadership Styles (Autocratic and Democratic) of School Administrators and the Mobbing Teachers Suffer. European Journal of Contemporary Education, 7(1), 150-164.

Potter, E. H., \& Rosenbach, W.E. (2006). "Followers as Partners: The Spirit of Leadership." In Contemporary Issues in Leadership (6th ed.)(143-153). Boulder, CO: Westview Press.

Ricketts, K. G. (2009). Followership:Translating Leadership Theory into Practice. Retrieved february 5, 2011, from http://www.ca.uky.edu/agc/pubs/elk1/elk1205/elk1205.pdf

Sanford. F. H. (1950). Authoritarianism and Leadesrhip: A study of the follower's orientation to authority.Philidelphia: Institute for Human Relations.

Schwartz, B. (1986). The battle for human nature. New York: W. W. Norton.

Sigmund, F. (1921/2001) Group Psychology and the Analysis of the Ego, SE XVIII. London: Vintage. 
178 Abbas, S.A - Extrovert Followership and its Impact on Agreeable Leadership

Steger, J.A., Manners, G. E., Jr., \& Zimmerer, T.W. (1982). Following the leader: How to link management style to subordinate personalities. Management Review, 71, 22-28, 49-51.

Vanderslice, V. J. (1988). Separating Leadership from Leaders: An Assessment of the Effect of Leader and Follower Roles in Organizations. Human Relations, Vol 41, Issue 9, pp. 677 - 696. https://doi.org/10.1177\%2F001872678804100903

Wortman, M. S., Jr. (1982). Strategic Management and Changing LeaderFollower Roles. The Journal of Applied Behavioral Science, 18(3), 371-383. https://doi.org/10.1177\%2F002188638201800310 
Syed Ali Abbas is a PhD (A.B.D) Business Administration, at Turiba University Riga and holds master's degree in Business Management \& Entrepreneurship from SAMK, Finland with another MBA degree from UVAS, Lahore.

He has been recently involved in teaching assignment at Poznan University of Economics Poland under Erasmus Mobility and has also served as lecturer in University of Economics and Management, Prague under the same mobility program.

Previously, he has been associated with IB\&M - University of Engineering and Technology Lahore in the capacity of lecturer and been an attendee of research methodology course at BI Norwegian Business School, Oslo Norway.

Research interests: entrepreneurship and SME growth; Higher Education Branding; Leadership.

Contact Address: Faculty of Business Administration, Turiba University, Latvia

E-mail: aabbas724@gmail.com ; ali.abbas@uet.edu.pk

ORCID ID: $\underline{\text { http://orcid.org/0000-0002-3634-6615 }}$

Scopus Author ID: 57201472949 